\title{
Effects of the Chin-Tuck Maneuver on Anatomical Changes and Angles during Swallowing: A Systematic Review
}

\author{
Dong-Hwan Oh, O.T., Han-Sol Park, Ga-Eun Kim \\ Department of Occupational Therapy, Kyungdong University, Wonju, Korea
}

Objective: This study aimed at providing a critical review of the overall benefits of the chin-tuck maneuver through a systematic review of its effects when used in the treatment of dysphagia, as well as to provide basic data for a comparative analysis in future studies.

Methods: To identify academic papers on the chin-tuck maneuver published from January 2000 to January 2021, a literature search on three databases was performed using keywords, including chin-tuck, dysphagia, and head flexion. Out of the 712 related papers identified, the methodological characteristics and results of 12 selected studies were reviewed.

Results: Nine of the 12 studies found that the chin-tuck position not only helped in the opening of the upper esophageal sphincter (UES) but also reduced pharyngeal residues and prevented aspiration and penetration. In addition, three studies analyzed the position of the neck flexion angle and the changing angle when performing the chin-tuck maneuver.

Conclusion: This shows that the chin-tuck maneuver is an effective strategy in the treatment of dysphagia. In future studies, further investigation of the posture, angles, and effects of the chin-tuck maneuver, could help identify additional benefits of this treatment. (JKDS 2022;12:1-13)

Keywords: Chin-tuck, Chin-down, Dysphagia, Aspiration, Angle

\section{INTRODUCTION}

Dysphagia is a condition characterized by difficulties in moving liquid or solid bolus from the mouth to the pharynx, larynx, and esophagus ${ }^{1}$. This may lead to various complications such as malnutrition, dehydration, pneumonia, and asphyxia ${ }^{2}$. Strategies for the prevention and treatment of dysphagia can be largely divided into compensatory and rehabilitation methods ${ }^{3}$. Compensatory approaches include food modification, postural changes, and compensatory maneuvers ${ }^{4}$. Among them, postural changes include the chin-tuck, head rotation, head back, and side-lying positions ${ }^{4,5}$, and these are performed to protect patients during eating and drinking ${ }^{6}$. Rehabilitation methods include neuromuscular electrical stimulation (NMES),

Received: June 28 2021, Revised: June 28 2021, Accepted: September 232021

Corresponding author: Dong-Hwan Oh, Department of Occupational Therapy, Kyungdong University, 815 Gyeonhwon-ro, Munmak-eup, Wonju 26495, Korea

Tel: +82-33-738-1394, Fax: +82-33-738-1399, E-mail: dhoh@kduniv.ac.kr

(i) \$ This is an Open Access article distributed under the terms of the Creative Commons Attribution Non-Commercial License, which permits unrestricted non-commercial use, distribution, and reproduction in any medium, provided the original work is properly cited. Copyrights (c) The Korean Dysphagia Society, 2022. 
the shaker exercise, the Mendelson maneuver, and effortful swallow ${ }^{7,8}$, and these are performed to facilitate the recovery process ${ }^{6}$.

The compensatory chin-tuck maneuver is defined as a movement that pulls the chin toward the chest $^{9,10}$, and it is commonly employed in clinical practice $^{2,11}$. The effects of this posture are as follows: First, it helps swallowing by reducing the laryngohyoid and hyoid-mandibular distances to loosen the pharyngeal constrictor muscle, thereby reducing the resistance of the surrounding tissues ${ }^{12}$. Second, it widens the epiglottic vallecula and narrows the airways and, thus, is useful for patients with aspiration ${ }^{10}$. Third, the chin-down posture-induced posterior shift of the tongue base fosters the bolus flow into the esophagus $^{13}$. Various studies have shown these effects; therefore, the chin-tuck maneuver has been widely adopted; however, some studies demonstrated inconsistency in the definitions of the position and its effects. And not only Chin tuck, but also head flexion and neck flexion showed a lack of unity in posture definition. The head flexion position is flexion of the head on the neck ${ }^{14}$, which is positioned perpendicular to the larynx entrance to help prevent aspiration $^{15}$. Neck flexion is a position that bends the cervical spine ${ }^{14}$ and reduces the distance between the larynx to make food control effective ${ }^{16}$. Despite this difference, Okada et al. ${ }^{17}$ reported that head flexion and neck flexion are mixed in treatment for dysphagia. In addition, although a number of studies have reported on the chin-tuck maneuver, no systematic reviews have been conducted. Therefore, the purpose of this study is to verify and summarize the overall effectiveness of the chin-tuck maneuver when applied in clinical practice through a systematic review of its effects when used in dysphagia treatment. In addition, the study aimed to provide basic data for comparative analysis in future studies. Overall, these findings can be used to aid dysphagia treatment, as well as to guide future research.

\section{METHODS}

\section{Literature search strategy}

1) Literature search: databases and search keywords

The search period for this study was from 2000 to January 2021, and databases such as PubMed (https:// pubmed.ncbi,mlm,mih,gov/), Scopus (https://www. scopus.com/home.uri), and Google Scholar (https:// scholar.google.com/) were searched. The general search equation "(swallow* OR deglutition OR dysphagia OR deglutition disorders OR aspiration) AND (chin tuck OR chin down OR head flexion OR neck flexion) AND (therapeutic position OR therapy OR position OR posture)" was used for main search. As a number of studies have used the terms "chin-tuck" and "chin-down" with the same meaning ${ }^{17}$, in this study, these terms were used interchangeably to broaden the scope of the review.

\section{2) Inclusion and exclusion criteria}

Exclusion criteria for this study were animal studies, patient populations related to postoperative deglutination disorders, conditions related to cancer, studies on chin tuck against resistance exercise, age conditions (children under 19 years of age), and research not published in English or with no English translation available. However, studies that reported the cervical angles of the chin tuck exercise or addressed the potential impact on the prevention of aspiration were included in the analysis. The searched papers were systematically reviewed regardless of the study design. Additional literature was obtained by searching the bibliographies of all included papers and additional websites.

\section{3) Literature selection process}

Three researchers used the same search equation to perform the review individually and collect literature. When there was a disagreement between the researchers regarding the selection of literature, the abstract and discussion were reviewed to reach an agreement. Nine papers satisfying the above inclusion and exclusion criteria were selected and, with further inclusion of three papers, a total of 12 papers were reviewed. In order to confirm the appropriateness of 
the literature, a professor specializing in occupational therapy reviewed the selected literature. The literature selection process is depicted in a Preferred Reporting Items for Systematic Reviews and MetaAnalyses (PRISMA) diagram, as shown in Fig. 1.

\section{4) Quality assessment}

In this study, the Jadad scale was used to evaluate the quality of the finally selected literature, as shown in Table 1. The Jadad scale is a procedure to independently assess the methodological quality of a clinical trial ${ }^{18}$. The National Institutes of Health (NIH) tool was used to complete a quality assessment of four studies using a single group pre-post design. As shown in Table 2, all studies were considered 'Good'. All assessments were conducted by a occupational therapists with more than 10 years of experience.

\section{RESULTS}

For the 12 selected studies, the populations included healthy subjects ${ }^{4,12,19-23}$, patients diagnosed with dysphagia ${ }^{2,13,24}$, or patients with neurologic disorders (e.g., stroke, acquired brain injury, or traumatic brain injury $)^{11,25}$. The average age was grouped based on the definitions of old age and adults by the World Health Organization and,

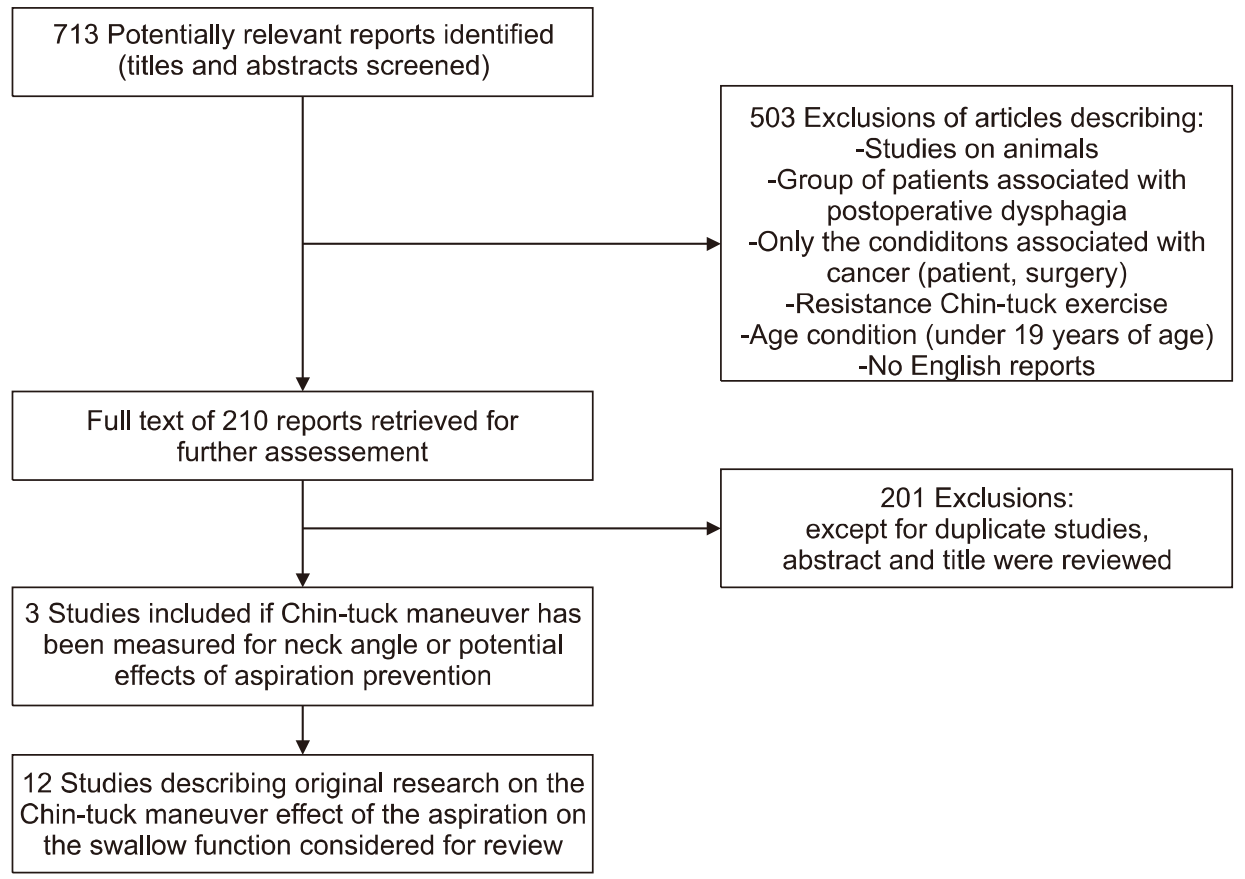

Fig. 1. Systematic review flowchart.

Table 1. Jadad scale for RCT quality assessments.

\begin{tabular}{lccccc}
\hline \multirow{2}{*}{ Study } & \multicolumn{3}{c}{ Jadad scale } & Total & General quality \\
\cline { 2 - 4 } & Randomization & Double blinding & Withdrawals and dropouts & \\
\hline Fraser $^{25}$ & 1 & 1 & 0 & 2 & High quality \\
Kim $^{23}$ & 1 & 0 & 0 & 1 & Low quality \\
Matsubara $^{20}$ & 1 & 1 & 0 & 2 & High quality \\
Leigh $^{41}$ & 1 & 1 & 0 & 2 & Low quality \\
Hyun $^{11}$ & 0 & 1 & 0 & 3 & Low quality \\
Steele $^{21}$ & 1 & 1 & 1 & 2 & High quality \\
Ra $^{2}$ & 1 & 0 & 1 & 2 & High quality \\
Ko $^{24}$ & 1 & 0 & 1 & High quality \\
\hline
\end{tabular}


Table 2. NHI rating of bias using the quality assessment tool for before-after studies.

\begin{tabular}{|c|c|c|c|c|c|c|c|c|c|c|c|c|}
\hline \multirow[b]{2}{*}{ Study } & \multicolumn{11}{|c|}{$\mathrm{NHI}$ rating } & \multirow[b]{2}{*}{$\begin{array}{l}\text { Quality } \\
\text { rating } \\
\text { (good, } \\
\text { fair and } \\
\text { poor) }\end{array}$} \\
\hline & $\begin{array}{c}\text { Study } \\
\text { question }\end{array}$ & $\begin{array}{l}\text { Eligibility } \\
\text { criteria } \\
\text { and } \\
\text { study } \\
\text { popula- } \\
\text { tion }\end{array}$ & $\begin{array}{l}\text { Study } \\
\text { participants } \\
\text { represen- } \\
\text { tative of } \\
\text { clinical } \\
\text { populations } \\
\text { of interest }\end{array}$ & $\begin{array}{c}\text { All } \\
\text { eligible } \\
\text { partici- } \\
\text { pants } \\
\text { enrolled }\end{array}$ & $\begin{array}{l}\text { Sample } \\
\text { size }\end{array}$ & $\begin{array}{c}\text { Intervention } \\
\text { clearly } \\
\text { described }\end{array}$ & $\begin{array}{c}\text { Outcome } \\
\text { measures } \\
\text { clearly } \\
\text { described, } \\
\text { valid and } \\
\text { reliable }\end{array}$ & $\begin{array}{l}\text { Blinding } \\
\text { of } \\
\text { outcome } \\
\text { assessors }\end{array}$ & $\begin{array}{l}\text { Follow-up } \\
\text { rate }\end{array}$ & $\begin{array}{l}\text { Statistical } \\
\text { analysis }\end{array}$ & $\begin{array}{l}\text { Multiple } \\
\text { outcome } \\
\text { measures }\end{array}$ & \\
\hline Young ${ }^{19}$ & Yes & Yes & Yes & Yes & Yes & Yes & Yes & Yes & Yes & Yes & Yes & Good \\
\hline Alghadir $^{22}$ & Yes & Yes & Yes & Yes & NR & Yes & Yes & NA & Yes & Yes & NR & Good \\
\hline Solazzo $^{13}$ & Yes & Yes & Yes & Yes & NR & Yes & Yes & NR & Yes & NA & Yes & Good \\
\hline Bülow $^{12}$ & Yes & Yes & Yes & Yes & NR & Yes & Yes & NR & Yes & Yes & NR & Good \\
\hline
\end{tabular}

according to these definitions, three studies investigated older people ${ }^{2,13,25}$ and eight studies investigated adults $^{4,11,12,19-23}$. One paper was not specified in the sentence above because the average age was not given $^{24}$. Swallowing function was evaluated using a videofluoroscopic swallowing study (VFSS) $)^{2,4,11,13,19,20,22-25}$, angle measurements and analysis using digital video ${ }^{21,23}$, fiberoptic endoscopic evaluation of swallowing $(\mathrm{FEES})^{11}$, and videomanometric analysis ${ }^{12}$. The sample size had a median value of 200.5 , with a range between 8 and 408. The methodological characteristics and results of these studies are outlined in Table 3 .

\section{Anatomical changes}

Leigh et al. ${ }^{4}$ analyzed one swallow at various positions (neutral, chin-down, and chin-tuck) using VFSS; they concluded that during swallowing, the chin-tuck position may aggravate opening of the upper esophageal sphincter (UES). Solazzo et al. ${ }^{13}$ used videofluoromanometry to analyze swallowing in dysphagia patients in the chin-down, head-turned, and hyperextended head positions, and the results showed complete opening of the UES in the chin-down position. Young et al. ${ }^{19}$ investigated anatomical changes in the chin-down and neutral positions using VFSS by dividing the swallowing event of dysphagia patients into eight steps, with UES opening confirmed at step 4. Bülow et al. ${ }^{12}$ examined anatomical changes in supraglottic swallow, effortful swallow, and swallowing in the chin-tuck position for healthy adults with simultaneous application of videoradiography and solid-state manometry. The found that swallowing in the chin-tuck position significantly reduced the laryngo-hyoid and hyoidmandibular distances. This reduction in the movement of anatomical structures shortens the path for laryngeal elevation in case of airway obstruction, demonstrating the beneficial effects of the chin-tuck maneuver.

\section{Efficiency and stability of swallowing}

Hyun et al. ${ }^{11}$ evaluated aspiration and penetration and the severity of pharyngeal residues associated with the chin-tuck position by simultaneously performing VFSS and FEES after administering chin-tuck training for at least 1 week in dysphagia patients. The evaluation was performed using the modified Penetration-Aspiration Scale, Pharyngeal Residue Severity Scale, and a newly developed scale, and, consequently, it was confirmed that the chin-tuck position was effective in reducing pharyngeal residues and preventing aspiration and penetration. Leigh et al. ${ }^{4}$ hypothesized that laryngeal penetration and aspiration could be reduced in the chin-down or chin-tuck positions and analyzed the swallowing process for healthy adults using VFSS. The results showed that in the chin-tuck position, the laryngeal inlet was shortened and the movement of the larynx was 
Table 3. Detailed description of the studies addressing the effects of the chin tuck maneuver on the swallow function.

\begin{tabular}{|c|c|c|c|c|}
\hline References & Sample \& Instruction & Outcome(s) & Results & Author's conclusions \\
\hline Fraser $^{25}$ & $\begin{array}{l}\text { Sample size: } \\
\text { Enrolled: } n=42 \\
\text { Age, mean (range): } 75 \\
\quad \text { (39-92) } \\
\text { Design: Clinical trial } \\
\quad \text { (patients) Instruction: } \\
\text { Chin-down position } \\
\text { (flexion of both the } \\
\text { head and neck in the } \\
\text { anterior direction). }\end{array}$ & $\begin{array}{l}\text { Videofluoroscopy of } \\
\text { deglutition to evaluate: } \\
\text { (1) frequencies of airway } \\
\text { invasion scores by } \\
\text { bolus delivery method } \\
\text { and head position; } \\
\text { (2) the angle (in degrees) } \\
\text { made by a line running } \\
\text { along the lower margin } \\
\text { of the mandibular } \\
\text { ramus and a vertical } \\
\text { line running through } \\
\text { the anterior. }\end{array}$ & $\begin{array}{l}\text { Similar curvature at the chin } \\
\text { angles of } 77^{\circ}(95 \% \text { confidence } \\
\left.\text { interval: } 70^{\circ} \text { to } 84^{\circ}\right) \text { and } \\
76^{\circ}(95 \% \text { confidence interval: } \\
\left.71^{\circ} \text { to } 80^{\circ}\right) \text { in Teaspoon and } \\
\text { cup swallows. } \\
\text { Not significantly different in the } \\
\text { Stroke and GIM (General } \\
\text { Internal Medicine) results } \\
\text { in the two groups were not } \\
\text { significantly different in the } \\
\text { Stroke and GIM. } \\
\text { In the chin down position, cup } \\
\text { swallows show normal airway, } \\
\text { but teaspoons worsen } \\
\text { swallowing stability. }\end{array}$ & $\begin{array}{l}\text { Chin down position is } \\
\text { not always beneficial. } \\
\text { Teaspoon administration } \\
\text { should not be used } \\
\text { unless clearly } \\
\text { demonstrated using } \\
\text { VFSS. }\end{array}$ \\
\hline $\mathrm{Kim}^{23}$ & $\begin{array}{l}\text { Sample size: } \\
\text { Enrolled: } n=37 \\
\text { Age, mean } \pm \text { SD (range): } \\
\quad 42.7 \pm 19.7 \text { (20-75) } \\
\text { Design: Clinical trial } \\
\quad \text { (healthy subjects) } \\
\text { Instruction: Retraction } \\
\text { posture (tuck your } \\
\text { chin as close to your } \\
\text { neck as possible). }\end{array}$ & $\begin{array}{l}\text { A videoflurographic } \\
\text { swallowing study was } \\
\text { performed in the } \\
\text { neutral and retracted } \\
\text { neck posture: } \\
\text { In neutral posture: } \\
\text { (1) changes in the angle } \\
\text { of the cervical spine; } \\
\text { (2) X,Y movements } \\
\text { (anterior-posterior } \\
\text { direction) of the } \\
\text { cervical spine. } \\
\text { In retraction posture: } \\
\text { (1) changes in the angle } \\
\text { of the cervical spine; } \\
\text { (2) X,Y movements } \\
\text { (anterior-posterior } \\
\text { direction) of the } \\
\text { cervical spine. }\end{array}$ & $\begin{array}{l}\text { In the neutral posture: } \\
\text { - } \text { C1 and C2 were flexed, } \\
\text { while C5, C6, and C7 were } \\
\text { extended. C3, C4, C5, C6, and } \\
\text { C7 moved posteriorly; } \\
\text { - all cervical levels, except for } \\
\text { C5, moved superiorly; } \\
\text { - total lordosis angle ranging } \\
\text { from C0 to C7 was } 22.34^{\circ} \\
\text { in the oral phase and } 21.14^{\circ} \\
\text { in the pharyngeal phase. } \\
\text { In the retraction posture: } \\
\text { all cervical levels moved } \\
\text { posteriorly: } \\
\text { - C0 and C1 were flexed, } \\
\text { while C6 was extended during } \\
\text { swallowing; } \\
\text { - C1, C2, C3, and C4 moved } \\
\text { superiorly; } \\
\text { - total kyphosis angle ranging } \\
\text { from C0 to C7 was } 12.54^{\circ} \\
\text { in the oral phase and } 14.77^{\circ} \\
\text { in the pharyngeal phase. } \\
\text { The comparison between } \\
2 \text { postures shows that angle } \\
\text { change is significantly different } \\
\text { between C0, C2, and C5. } \\
\text { Superior movement is significantly } \\
\text { different in C0. }\end{array}$ & $\begin{array}{l}\text { C0 segment is most } \\
\text { significantly different } \\
\text { between neutral and } \\
\text { retraction posture in } \\
\text { terms of angle and } \\
\text { position change. } \\
\text { Suggest that CO segment } \\
\text { could be a critical } \\
\text { level of compensation } \\
\text { that allows swallowing } \\
\text { even in the retraction } \\
\text { neck posture } \\
\text { regarding motion and } \\
\text { angle change. } \\
\text { Important not to do OC } \\
\text { fixation in retraction } \\
\text { posture. } \\
\text { Sparing C0 segment } \\
\text { could provide some } \\
\text { degree of freedom } \\
\text { for the compensatory } \\
\text { movement and angle } \\
\text { change to avoid } \\
\text { dysphagia after OC } \\
\text { fixation. }\end{array}$ \\
\hline
\end{tabular}

reduced, leading to effective airway protection. Matsubara et al. ${ }^{20}$ compared the swallowing pressure of three techniques (head flexion, neck flexion, and combined head and neck flexion) in healthy adults using high-resolution manometry. The results showed that in the chin-down position, penetration and aspiration were minimized by expanding the epiglottic vallecula and narrowing the laryngeal inlet. In addition, using VFSS, Ko et al. ${ }^{24}$ investigated the effects of the chin-tuck position on penetration and aspiration in patients with swallowing disorders, as well as factors affecting chin tuck effectiveness; they found that the chin-tuck position reduces the depth and rate of aspiration and also reduces the amount 
Table 3. Continued 1.

\begin{tabular}{|c|c|c|c|c|}
\hline References & Sample & Outcome(s) & Results & Author's conclusions \\
\hline Matsubara $^{20}$ & $\begin{array}{l}\text { Sample size: } \\
\text { Enrolled: n=26 } \\
\text { Age, mean (range): } \\
\text { 26.4 (21-35) } \\
\text { Design: Clinical trial } \\
\text { (healthy subjects) } \\
\text { Instruction: The three } \\
\text { positions of chin } \\
\text { down (HF, NF, } \\
\text { HFNF). }\end{array}$ & $\begin{array}{l}\text { Evaluation during the exercises: } \\
\text { solid-state HRM was used for all } \\
\text { data collection: } \\
\text { (1) neutral position as the control; } \\
\text { (2) Head flexion (HF), Neck flexion } \\
\text { (NF); } \\
\text { (3) combined Head and Neck flexion } \\
\text { (HFNF). } \\
\text { HRM to evaluate: } \\
\text { (1) comparison of the effects of the } \\
\text { three techniques (HF, NF, HFNF) } \\
\text { on strengthening Swallowing by } \\
\text { location. }\end{array}$ & $\begin{array}{l}\text { Not significantly differ } \\
\text { among the three } \\
\text { chin-down positions is } \\
\text { the MSP at the } \\
\text { velopharynx and } \\
\text { meso-hypopharynx. } \\
\text { Significantly lower } \\
\text { ( }<<0.0001) \text { at the UES } \\
\text { is upon swallowing } \\
\text { in the NF posture, the } \\
\text { MSP. } \\
\text { Duration of the lowered } \\
\text { SP at the UES: } \\
\text { - significantly prolonged } \\
\text { (P<0.0010) compared } \\
\text { to theneutral position; } \\
\text { significantly (P }<0.0001) \\
\text { shorter in the HF } \\
\text { position than in the } \\
\text { neutral position; } \\
\text { the HFNF position } \\
\text { significantly ( }<<0.0276) \\
\text { lowered the MSP at the } \\
\text { UES compared to the } \\
\text { control position. }\end{array}$ & $\begin{array}{l}\text { In young healthy adults, } \\
\text { NF maneuver resulted } \\
\text { in significantly lower } \\
\text { MSP and longer } \\
\text { duration of the } \\
\text { lowered swallowing } \\
\text { pressure at the UES, } \\
\text { which might assist } \\
\text { bolus passage through } \\
\text { the UES. } \\
\text { Duration of lowered SP } \\
\text { at the UES: } \\
\text { The NF position would } \\
\text { facilitate bolus passage } \\
\text { through the UES, } \\
\text { whereas the HF } \\
\text { position would hinder } \\
\text { passage. } \\
\text { Therefore, we speculated } \\
\text { that greater } \\
\text { subatmospheric } \\
\text { pressure in the UES in } \\
\text { the chin-down position } \\
\text { is related to relatively } \\
\text { increased mandible } \\
\text { descent and is } \\
\text { advantageous for } \\
\text { improving bolus } \\
\text { passage. }\end{array}$ \\
\hline Leigh $^{4}$ & $\begin{array}{l}\text { Sample size: } \\
\text { Enrolled: } \mathrm{n}=40 \\
\text { Age, mean } \pm \text { SD: } \\
52.9 \pm 17.9 \\
\text { Design: Clinical trial } \\
\text { (healthy subjects) } \\
\text { Instruction: normal } \\
\text { and comfortable } \\
\text { position (NEUT), } \\
\text { a comfortable } \\
\text { chin-down } \\
\text { position (DOWN), } \\
\text { and a strict } \\
\text { chin-down } \\
\text { position (TUCK). }\end{array}$ & $\begin{array}{l}\text { Videofluoroscopy of deglutition } \\
\text { to evaluate: } \\
\text { (1) the chin-cervical spine, epiglottic } \\
\text { base-cervical spine, and epiglottic } \\
\text { base arytenoid distances (mm) at } \\
\text { rest just before swallowing; } \\
\text { (2) the maximal vertical and } \\
\text { horizontal excursions (mm) of the } \\
\text { hyoid, epiglottic base, and vocal } \\
\text { cords (upper margin of the } \\
\text { subglottic airway column); } \\
\text { (3) the maximal vertical and } \\
\text { horizontal } 2 \mathrm{D} \text { velocities (mm/s) } \\
\text { of the hyoid, Epiglottic base, } \\
\text { and vocal cords, defined as the } \\
\text { points with maximal velocity } \\
\text { along each direction and the } \\
\text { velocity of the bolus head. }\end{array}$ & $\begin{array}{l}\text { Between exercise } \\
\text { comparison (NEUT vs. } \\
\text { DOWN vs. TUCK) } \\
\text { No significantly different } \\
\text { the hyoid bone among } \\
\text { the three postures. } \\
\text { The maximal angle of } \\
\text { epiglottic rotation also } \\
\text { increased from NEUT } \\
\text { to DOWN and TUCK, } \\
\text { but the trend was not } \\
\text { significant. } \\
\text { Reducing the width of the } \\
\text { oropharynx is TUCK may } \\
\text { ease swallowing in } \\
\text { patients with weak } \\
\text { tongue-base retraction. } \\
\text { TUCK resulted in decreased } \\
\text { UES pressure. }\end{array}$ & $\begin{array}{l}\text { Chin-tuck posture } \\
\text { facilitates airway } \\
\text { protection and } \\
\text { enhances tongue base } \\
\text { retraction. } \\
\text { Only the chin-down } \\
\text { posture may be } \\
\text { effective to adequately } \\
\text { widen the vallecular } \\
\text { space, and it is } \\
\text { important to instruct } \\
\text { patients in the exact } \\
\text { chin-tuck posture, } \\
\text { which can provide } \\
\text { essential airway } \\
\text { protection. } \\
\text { The exact chin-tuck has } \\
\text { the possibility of } \\
\text { reducing the UES } \\
\text { opening. }\end{array}$ \\
\hline
\end{tabular}

of pharyngeal residues.

\section{Angle}

Ra et al. $^{2}$ analyzed the angle between the mandibular bone and the horizontal line connecting to the front of the $\mathrm{C} 2$ vertebrae in the chin-tuck position for dysphagia patients using the receiver operating characteristic curve, and the results showed that the 
Table 3. Continued 2

\begin{tabular}{|c|c|c|c|c|}
\hline References & Sample & Outcome(s) & Results & Author's conclusions \\
\hline Hyun $^{11}$ & $\begin{array}{l}\text { Sample size: } \\
\text { Enrolled: } \mathrm{n}=35 \\
\text { Age, mean } \pm \mathrm{SD} \text { : } \\
\quad 64.2 \pm 12.1 \\
\text { Design: Clinical trial } \\
\quad \text { (patients) } \\
\text { Instruction: Chin-tuck } \\
\quad \text { (tuck their chin } \\
\text { toward their chest). }\end{array}$ & $\begin{array}{l}\text { VFSS and FEES simultaneously } \\
\text { VFSS: } \\
\text { The swallowing studies were } \\
\text { performed by swallowing } \\
2 \mathrm{~mL} \text { of fluid containing } \\
35 \% \text { diluted barium solution: } \\
\text { (Discrimination during FEES) } \\
\text { (1) rice porridge with green } \\
\text { coloring; } \\
\text { (2) curd-type yogurt with blue } \\
\text { coloring; } \\
\text { (3) thin fluid with black coloring. } \\
\text { Videofluoroscopy of deglutition } \\
\text { to evaluate: } \\
\text { (1) the presence of penetration } \\
\text { or aspiration and the severity } \\
\text { of pharyngeal residues; } \\
\text { (2) the pharyngeal residue } \\
\text { severity scale. } \\
\text { Fiberoptic Endoscopic of } \\
\text { deglutition to evaluate: } \\
\text { (1) Information about the right } \\
\text { and the left side residues } \\
\text { individually. }\end{array}$ & $\begin{array}{l}\text { Significant decrease when } \\
\text { subjects swallowed thin } \\
\text { liquid with chin tuck } \\
\text { maneuver only in VFSS } \\
\text { (P=0.02). } \\
\text { No change in the mPAS } \\
\text { for swallowing rice porridge } \\
\text { or curd-type yogurt } \\
\text { between neutral or chin } \\
\text { tuck posture in VFSS, and } \\
\text { FEES did not reveal any } \\
\text { significant decrease in the } \\
\text { mPAS. } \\
\text { Decrease in the vallecular } \\
\text { residues by chin tuck } \\
\text { posture in rice porridge, } \\
\text { and thin liquid. }\end{array}$ & $\begin{array}{l}\text { Chin tuck maneuver was } \\
\text { effective in preventing } \\
\text { aspiration or penetration } \\
\text { and in reducing } \\
\text { pharyngeal residues as } \\
\text { documented by both VFSS } \\
\text { and FEES. } \\
\text { New scale for pharyngeal } \\
\text { residues is especially } \\
\text { valuable since it enables } \\
\text { the three-dimensional } \\
\text { structure of the } \\
\text { pharyngeal cavity to be } \\
\text { considered when using } \\
\text { this method. }\end{array}$ \\
\hline Steele $e^{21}$ & $\begin{array}{l}\text { Sample size: } \\
\text { Enrolled: } \mathrm{n}=408 \\
\text { Age-range: } 18-80 \\
\text { Design: Clinical trial } \\
\text { (healthy subjects) } \\
\text { Instruction: } \\
\quad \text { Head-neutral, } \\
\text { Chin-down } \\
\text { (a flexed position). }\end{array}$ & $\begin{array}{l}\text { Videofluoroscopy of deglutition } \\
\text { to evaluate: } \\
\text { (a) head-neutral water swallow } \\
\text { mean head angle; } \\
\text { (b) chin-down water swallow } \\
\text { mean head angle; } \\
\text { (c) chin-down water swallow } \\
\text { maximum head angle. Group } \\
\text { means and standard } \\
\text { deviations for these measures } \\
\text { were calculated by gender } \\
\text { and age category (i.e., } 35 \text {, } \\
36-50,51-65 \text { and }>65 \text { years } \\
\text { of age). }\end{array}$ & $\begin{array}{l}\text { No gender differences } \\
\text { were found for the mean } \\
\text { chindown } \\
\text { ( } \mathrm{P}=0.10) \text { and maximum } \\
\text { chin-down }(\mathrm{P}=0.13) \\
\text { measures. } \\
\text { No significant age-group by } \\
\text { gender interactions were } \\
\text { identified. } \\
\text { Perform the chin tuck posture, } \\
\text { the average angle mean: } \\
\text { the chin down is } 78.2 \pm 9.81 \text {; } \\
\text { - the maximum chin } \\
\text { down is } 52.5 \pm 11.1 \\
\text { on average; } \\
\text { Not find significant } \\
\text { differences between } \\
\text { age groups in any of } \\
\text { the head angle position } \\
\text { measurements mean head } \\
\text { neutral angle. }\end{array}$ & $\begin{array}{l}\text { The results of this study } \\
\text { suggest that healthy } \\
\text { individuals flex their } \\
\text { necks by approximately } \\
19 \text { degrees (on verage) } \\
\text { compared to a natural } \\
\text { (head-neutral) drinking } \\
\text { position, when instructed } \\
\text { to perform a chin-down } \\
\text { maneuver. } \\
\text { On average, head angle } \\
\text { varied as much as a } \\
\text { further } 25^{\circ} \text { between the } \\
\text { mean and maximum head } \\
\text { flexion measures in water } \\
\text { swallows employing a } \\
\text { chin-down posture in } \\
\text { this study. } \\
\text { This study did not attempt to } \\
\text { investigate the temporal } \\
\text { aspect of the Chin down } \\
\text { posture. }\end{array}$ \\
\hline
\end{tabular}

optimal angle for preventing aspiration was $17.5^{\circ}$. Steele et al. ${ }^{21}$ analyzed the swallowing of water in the neutral and chin-down positions for healthy adults through an angle- measurement program (LabVIEW, Medix 3000), and the results showed an average flexion of $19^{\circ}$. Kim et al. ${ }^{23}$ compared changes in the angle and position of the hyoid bone in relation to the $\mathrm{CO}$ to $\mathrm{C} 7$ vertebrae in the neutral and chin-tuck positions in healthy adults; they found that in the chin-tuck position, the angle change was most pronounced at $\mathrm{CO}$. 
Table 3. Continued 3.

\begin{tabular}{|c|c|c|c|c|}
\hline References & Sample & Outcome(s) & Results & Author's conclusions \\
\hline Young $^{19}$ & $\begin{array}{l}\text { Sample size: } \\
\text { Enrolled: n=16 } \\
\text { Age, mean (range): } \\
33.2 \text { (21-54) } \\
\text { Design: A before-after } \\
\text { trial (healthy } \\
\text { subjects) } \\
\text { Instruction: chin-down } \\
\text { posture. }\end{array}$ & $\begin{array}{l}5 \text { Neutral head position, } 30 \\
\text { chin-down posture, and then } \\
10 \text { neutral head position. } \\
\text { Eight swallowing events were } \\
\text { measured using } \\
\text { Videofluoroscopy: } \\
\text { (1) the time of hyoid burst; } \\
\text { (2) bolus head and tail in the } \\
\text { pharynx; } \\
\text { (3) laryngeal vestibule closure (LVC); } \\
\text { (4) upper esophageal sphincter } \\
\text { (UES) opening; } \\
\text { (5) bolus head in the UES, bolus } \\
\text { tail exiting the pharynx, and } \\
\text { laryngeal vestibule opening (LVO). }\end{array}$ & $\begin{array}{l}\text { LVC was one of the first } 3 \\
\text { swallowing events in } 69 \% \\
\text { of neutral swallows and } \\
\text { in } 78 \% \text { of chin-down } \\
\text { swallows ( } \mathrm{P}=.006 \text { ). } \\
\text { LVO occurred last in } 14 \% \text { of } \\
\text { chin-down swallows. } \\
\text { Never occurred last in the } \\
\text { preceding neutral swallows } \\
(\mathrm{P} \leq .001) \text {. }\end{array}$ & $\begin{array}{l}\text { Our results showed that } \\
\text { the chin-down } \\
\text { posture could be } \\
\text { appropriate for } \\
\text { individuals with } \\
\text { delayed onset of LVC } \\
\text { or short duration of } \\
\text { LVC. } \\
\text { The effect could be } \\
\text { transient when } \\
\text { performed repeatedly } \\
\text { and does not appear } \\
\text { to generalize to } \\
\text { subsequent swallows } \\
\text { in the head-neutral } \\
\text { position. }\end{array}$ \\
\hline $\mathrm{Ra}^{2}$ & $\begin{array}{l}\text { Sample size: } \\
\text { Enrolled: } \mathrm{n}=97 \\
\text { Age, mean } \pm \text { SD: } \\
\quad 67.1 \pm 13.7 \\
\text { Design: Clinical trial } \\
\quad \text { (patients) } \\
\text { Instruction: Chin tuck } \\
\text { (chin touching the } \\
\text { chest). }\end{array}$ & $\begin{array}{l}\text { Videofluoroscopy of deglutition to } \\
\text { evaluate: } \\
\text { The swallowing processes in the } \\
\text { oral phase: } \\
\text { (1) completeness of lip closure; } \\
\text { (2) presence of oral residue and } \\
\text { presence of premature bolus } \\
\text { leakage; } \\
\text { (3) the oral transit time (OTT-the } \\
\text { time elapsed from backward } \\
\text { movement of bolus until the } \\
\text { bolus head reaches the lower } \\
\text { edge of the mandible). } \\
\text { The swallowing processes in the } \\
\text { pharyngeal phase: } \\
\text { (1) delay of triggering of pharyngeal } \\
\text { swallowing; } \\
\text { (2) height of laryngeal elevation } \\
\text { and presence of residue in the } \\
\text { valleculae and pyriformis sinus; } \\
\text { (3) the pharyngeal delayedtime (PDT) } \\
\text { and pharyngeal transit time (PTT). }\end{array}$ & $\begin{array}{l}\text { Significant decrease (more than } \\
\text { one scale) in 8PPAS scores } \\
\text { with the chin tuck method. } \\
\text { Significantly different between } \\
\text { groups, being }-3.3 \pm 2.7 \text { in } \\
\text { the EFF group and } 0.9 \pm 1.8 \\
\text { in the INEFF group } \\
\text { (P<0.001). } \\
\text { Significantly shortened in both, } \\
\text { Pharyngeal delayed time } \\
\text { and pharyngeal transit time } \\
\text { (P<0.05), but the difference } \\
\text { between the groups was not } \\
\text { significant. } \\
\text { The optimal neck flexion angle } \\
\text { was } 17.5 \text { (sensitivity }=0.737 \text {, } \\
\text { specificity=0.654). } \\
\text { Not statistically different } \\
\text { between the chin angle at } \\
\text { neutral and chin tuck and } \\
\text { lordosis angle at chin tuck } \\
\text { position. }\end{array}$ & $\begin{array}{l}\text { Patients without residue } \\
\text { in pyriform sinus } \\
\text { were more likely to } \\
\text { benefit from chin } \\
\text { tuck. } \\
\text { Sufficient neck flexion } \\
\text { is important and the } \\
\text { minimum neck } \\
\text { flexion (sum of } \\
\text { cervical and } \\
\text { atlanto-occipital } \\
\text { flexion) of } 17.5^{\circ} \text { is } \\
\text { required to acquire } \\
\text { a benefit from the } \\
\text { chin tuck method. }\end{array}$ \\
\hline
\end{tabular}

\section{DISCUSSION}

This study aimed to provide a critical review of the overall effects of the chin-tuck maneuver through a systemic review of the effects of this swallowing rehabilitation technique that is widely and frequently used in clinical practice and also to provide basic data for comparative analysis in further studies.

This study showed that although the level of effectiveness differed in the literature, the chin-tuck maneuver provides improvements in terms of pharyngeal residues, UES opening, pharyngeal delay time, and laryngeal elevation. This implies that the chin-tuck maneuver is effective in the treatment of dysphagia and, when the swallowing process was examined through various analysis tools, the chin tuck was confirmed to be effective. Several studies ${ }^{13,19,20}$ have evaluated the positive effects of the chin-tuck position in terms of increased UES opening; however, one report indicated that UES opening may worsen in the chin-tuck position ${ }^{4}$. A study by Leigh et al. ${ }^{4}$ investigated how the movements of the pharyngeal and laryngeal structures are affected by the head and neck positions during swallowing in three positions 
Table 3. Continued 4 .

\begin{tabular}{|c|c|c|c|c|}
\hline References & Sample & Outcome(s) & Results & Author's conclusions \\
\hline Alghadir $^{22}$ & $\begin{array}{l}\text { Sample size: } \\
\text { Enrolled: } \mathrm{n}=186 \\
\text { Age, mean } \pm \text { SD: } \\
52.9 \pm 17.9 \\
\text { Design: A } \\
\text { before-after trial } \\
\text { (patients) } \\
\text { Instruction: head } \\
\text { and neck flexion }\end{array}$ & $\begin{array}{l}\text { Statistically significant } \\
\text { differences were found } \\
\text { between sitting upright, } \\
\text { sitting with head/neck } \\
\text { flexed, head/neck } \\
\text { extended and lying } \\
\text { supine. } \\
\text { (1) upright sitting vs } \\
\text { head/neck flexion; } \\
\text { (2) upright sitting vs } \\
\text { head/neck extension; } \\
\text { (3) upright sitting vs } \\
\text { supine lying; } \\
\text { (4) head/neck flexion vs } \\
\text { head/neck extension; } \\
\text { (5) head/neck flexion vs } \\
\text { supine lying; } \\
\text { (6) head/neck extension } \\
\text { vs supine lying. }\end{array}$ & $\begin{array}{l}\text { Significant differences were found } \\
\text { between sitting upright, sitting } \\
\text { with head/neck flexed, head/neck } \\
\text { extended and lying supine. } \\
\text { Decrease in upper esophageal } \\
\text { sphincter relaxation and difficulty } \\
\text { in its closure during neck } \\
\text { extension. }\end{array}$ & $\begin{array}{l}\text { Chin tuck position makes the } \\
\text { vallecular space wide and } \\
\text { airway entrance narrow to } \\
\text { prevent aspiration and } \\
\text { decreases pharyngeal } \\
\text { contraction to decrease } \\
\text { dysphagia limit. } \\
\text { Rotation of head can facilitate } \\
\text { more efficient swallowing by } \\
\text { directing the flow of bolus } \\
\text { towards more sensate and } \\
\text { stronger side of pharynx } \\
\text { where pharyngeal cavities are } \\
\text { closed and facilitates the } \\
\text { opening of the upper } \\
\text { esophageal sphincter. } \\
\text { Postural modification may help } \\
\text { in treatment of dysphagia by } \\
\text { affecting bolus flow to } \\
\text { improve speed and safety of } \\
\text { swallowing by closure of } \\
\text { airways to prevent aspiration. }\end{array}$ \\
\hline Solazzo ${ }^{13}$ & $\begin{array}{l}\text { Sample size: } \\
\text { Enrolled: } \mathrm{n}=321 \\
\text { Age, mean } \pm \text { SD } \\
\text { (range): } \\
67.1 \pm 13.7 \text { (18-87) } \\
\text { Design: A } \\
\text { before-after trial } \\
\text { (patients) } \\
\text { Instruction: } \\
\text { Chin-down posture } \\
\text { (tuck the chin to } \\
\text { the neck) }\end{array}$ & $\begin{array}{l}\text { Videofluoroscopy of } \\
\text { deglutition to evaluate: } \\
\text { (1) compensatory postures } \\
\text { could correct the } \\
\text { swallowing disorder; } \\
\text { (2) the tongue base } \\
\text { pressure (the contact } \\
\text { pressure between the } \\
\text { posterior tongue thrust } \\
\text { and the pharyngeal } \\
\text { wall); } \\
\text { (3) UES tone (resting } \\
\text { pressure, contraction } \\
\text { pressure and residual } \\
\text { pressure); } \\
\text { (4) the bolus transit } \\
\text { coordination. }\end{array}$ & $\begin{array}{l}\text { The change in head position } \\
\text { inverted the epiglottis into a more } \\
\text { protective position over the airway } \\
\text { entry, which reduced the airway } \\
\text { entrance space and increased the } \\
\text { size of the vallecular spaces. } \\
\text { In all } 17 \text { patients, a total resolution } \\
\text { of the disorder was obtained by } \\
\text { adopting the chin-down posture. } \\
\text { The aspiration correction: } \\
\text { - } 78 \% \text { patients with reduced } \\
\text { laryngeal closure or elevation, } \\
\text { the chin-down posture; } \\
\text { - } 71 \% \text { patients with UES disorders } \\
\text { corrected with the head-turned } \\
\text { posture. } \\
\text { The chin-down posture solved the } \\
\text { aspiration in cases ( } 52.4 \%) \text {, and the } \\
\text { head-turned posture was useful in } \\
\text { patients ( } 42.9 \%) \text {. }\end{array}$ & $\begin{array}{l}\text { Chin-down posture resolved } \\
\text { the aspiration because it } \\
\text { placed the epiglottis in a } \\
\text { more protective position of } \\
\text { the airways and restricted } \\
\text { the airway entrance. } \\
\text { Chin down posture was useful } \\
\text { in all patients with aspiration } \\
\text { before swallowing because } \\
\text { it promoted bolus control } \\
\text { in the oral cavity until the } \\
\text { swallowing reflex was elicited. }\end{array}$ \\
\hline
\end{tabular}

(neutral, chin-tuck, and chin-down). They found that the chin-tuck reduced aspiration and helped swallowing, but the results also implied a risk of worsened UES opening, with reduced maximal horizontal displacement of the hyoid bone in case of excessive chin tuck. In addition, they proposed that these results could vary with age and that the appropriate posture should be determined depending on the age of patients. These findings imply that although the study was conducted in healthy people, the chin-tuck maneuver could aggravate UES opening. It can be expected that the worsening of UES opening will be more severe if the study is conducted in patients with conditions such as hypertonicity and spasticity, and further investigation is required for these patient populations.

The objectives of the chin-tuck maneuver for rehabilitating patients with dysphagia are to reduce 
Table 3. Continued 5.

\begin{tabular}{|c|c|c|c|c|}
\hline References & Sample & Outcome(s) & Results & Author's conclusions \\
\hline Bülow $^{12}$ & $\begin{array}{l}\text { Sample size: } \\
\text { Enrolled: } \mathrm{n}=8 \\
\text { Age, mean } \pm \mathrm{SD} \\
\text { (range): } \\
52.9 \pm 17.9(25-64) \\
\text { Design: A before-after } \\
\text { trial (healthy } \\
\text { subjects) } \\
\text { Instruction: Chin tuck } \\
\quad \text { (the forward flexion } \\
\text { of the head). }\end{array}$ & $\begin{array}{l}\text { Videofluoroscopy of deglutition to } \\
\text { evaluate: } \\
\text { Seven videoradiographic variables were } \\
\text { analyzed: } \\
\text { (1) bolus transit time; } \\
\text { (2) maximal hyoid movement; } \\
\text { (3) maximal laryngeal elevation; } \\
\text { (4) maximal laryngohyoid distance; } \\
\text { (5) minimal laryngohyoid distance; } \\
\text { (6) PES opening; } \\
\text { (7) hyoid-mandibular distance. } \\
\text { Six manometric variables were } \\
\text { analyzed: } \\
\text { (1) pharyngeal contraction pressure; } \\
\text { (2) pharyngeal contraction duration; } \\
\text { (3) PES relaxation; } \\
\text { (4) PES relaxation duration; } \\
\text { (5) PES contraction; } \\
\text { (6) coordination of PES-inferior } \\
\text { pharyngeal constrictor. }\end{array}$ & $\begin{array}{l}\text { Reduced all measured } \\
\text { distances in the } \\
\text { pharynx in all } \\
\text { volunteers. } \\
\text { Significant shortening was } \\
\text { found for the } \\
\text { following variables: } \\
\text { - maximal distance of the } \\
\text { laryngohyoid } \\
\text { Preswallow; } \\
\text { - minimal distance of the } \\
\text { laryngohyoid } \\
\text { during swallow; } \\
\text { - distance of the } \\
\text { hyoid-mandible } \\
\text { Preswallow. } \\
\text { Significantly reduced } \\
\text { pharyngeal peak } \\
\text { contraction pressure } \\
\text { and pharyngeal } \\
\text { contraction duration. }\end{array}$ & $\begin{array}{l}\text { Chin tuck, or chin down, } \\
\text { is one among different } \\
\text { postural techniques, } \\
\text { where the patient by } \\
\text { positioning the head } \\
\text { can facilitate } \\
\text { swallowing. } \\
\text { In chin tuck, decreased } \\
\text { distances between the } \\
\text { larynx and the hyoid } \\
\text { bone and also between } \\
\text { the hyoid bone and the } \\
\text { mandible. } \\
\text { These decreased } \\
\text { movements of } \\
\text { anatomical structures } \\
\text { may be the reason for } \\
\text { the effectiveness of the } \\
\text { technique by shortening } \\
\text { the route necessary for } \\
\text { laryngeal elevation in } \\
\text { the closure of the } \\
\text { airways. } \\
\text { In chin tuck, the } \\
\text { technique could worsen } \\
\text { the problems if the } \\
\text { patient has weak } \\
\text { pharyngeal constrictor } \\
\text { muscles, which could } \\
\text { cause great risk for } \\
\text { postswallow retention } \\
\text { and aspiration. }\end{array}$ \\
\hline $\mathrm{Ko}^{24}$ & $\begin{array}{l}\text { Sample size: } \\
\text { Enrolled: } \mathrm{n}=76 \\
\text { Age, mean } \pm \text { SD: } \\
\text { 65.62 } \pm 17.66 \\
\text { Design: A randomized } \\
\text { study (patients) } \\
\text { Instruction: Chin tuck } \\
\text { (also known as chin } \\
\text { down or neck } \\
\text { flexion). }\end{array}$ & $\begin{array}{l}\text { Videofluoroscopy of deglutition to } \\
\text { evaluate: } \\
\text { Presence of oral residue, and } \\
\text { premature bolus leakage were } \\
\text { assessed: } \\
\text { (1) the oral transit time (OTT). } \\
\text { Delayed triggering of pharyngeal } \\
\text { swallowing, height of laryngeal } \\
\text { elevation, and the presence of } \\
\text { residues in the valleculae and } \\
\text { pyriformis sinuses were } \\
\text { assessed: } \\
\text { (1) the pharyngeal delayed time (PDT); } \\
\text { (2) the pharyngeal transit time (PTT). }\end{array}$ & $\begin{array}{l}\text { The penetration depth is } \\
16.09 \pm 8.60 \mathrm{~mm} \text { in the } \\
\text { neutral position and } \\
13.18 \pm 8.63 \mathrm{~mm} \text { in the } \\
\text { Chin-tuck position. } \\
\text { The penetration ratio is } \\
0.56 \pm 0.26 \text { in the } \\
\text { neutral position and } \\
0.48 \pm 0.30 \text { in the } \\
\text { Chin-tuck position. } \\
\text { Pharyngeal residues in the } \\
\text { Chin-tuck position } \\
\text { were reduced in all } \\
\text { groups. }\end{array}$ & $\begin{array}{l}\text { The results showed that } \\
\text { Chin-tuck was less } \\
\text { effective than expected. } \\
\text { A significant decrease in } \\
\text { only one-third of } \\
\text { patients although } \\
\text { aspiration decreased, } \\
\text { we observed. }\end{array}$ \\
\hline
\end{tabular}

the pharyngeal delay time by controlling the flow of bolus, reduce the incidence of penetration and aspiration, and facilitate spontaneous swallowing ${ }^{26-28}$. Of the 12 papers analyzed in this review, most confirmed that the chin-tuck maneuver meets these objectives, as well as that the chin-tuck position prevented penetration and aspiration and facilitated the swallowing movements. However, some studies have reported that careful interpretation is required because the results may vary depending on the patient characteristics ${ }^{29,30}$. Saconato et al..$^{30}$ reported that the chin-tuck maneuver is effective in dysphagia 
Table 4. Pre- vs. post-evaluation of the chin-tuck (eleven studies).

\begin{tabular}{|c|c|c|c|c|c|c|}
\hline \multirow{3}{*}{ Outcome } & \multicolumn{6}{|c|}{$\begin{array}{l}\text { Number of studies assessing each outcome, according to the participants' } \\
\text { characteristics and the conclusions of the original articles }\end{array}$} \\
\hline & \multicolumn{3}{|c|}{ Dysphagic patients } & \multicolumn{3}{|c|}{ Not dysphagic } \\
\hline & Effective & Not effective & Total* & Effective & Not effective & Total* \\
\hline Reduced aspiration $(\mathrm{n}=10)$ & 4 & - & 4 & 6 & - & 6 \\
\hline Reduction of pharyngeal residue $(n=3)$ & 3 & - & 3 & - & - & - \\
\hline UES open $(n=4)$ & 1 & - & 1 & 2 & 1 & 3 \\
\hline Reduced laryngeal entrance distance $(n=2)$ & - & - & - & 2 & - & 2 \\
\hline Laryngeal elevation $(n=2)$ & 1 & - & 1 & 1 & - & 1 \\
\hline Airway closure $(n=1)$ & - & - & - & 1 & - & 1 \\
\hline Reduced hyoid horizontal movement $(n=1)$ & - & - & - & 1 & - & 1 \\
\hline $\begin{array}{l}\text { Reduced the distance of the posterior } \\
\text { pharyngeal wall }(n=1)\end{array}$ & - & - & - & 1 & - & 1 \\
\hline
\end{tabular}

*The sum of the studies assessing all of the outcomes is higher than 11 because each study may address more than one outcome.

patients with reduced pharyngeal delay time, reduced laryngeal elevation, and difficulties in swallowing liquids; however, in some patients with decreased oral sensation and reduced tongue mobility, the chin-tuck maneuver may cause extraoral leakage, and it is unlikely to be effective in these cases. In addition, Balou et al. ${ }^{29}$ confirmed that the application of the chin-tuck maneuver in patients with weak pharyngeal constrictor muscles may cause difficulty in swallowing and aspiration may occur. This could be a major drawback in elderly people whose muscle strength, stability, and control are reduced and in dysphagia patients due to various neurologic diseases; thus, the application of the chin-tuck maneuver in these patients requires careful consideration. In particular, although some studies have verified the negative effect of the chin-tuck maneuver in older people, there are no suggestions of appropriate alternatives reflecting physical changes in the elderly, and thus, further research is required. In addition, in this review, we could not identify any study on the most effective treatment method taking into account the decreased strength of the facial and masticatory muscles; therefore, further research in this area is also needed.

Finally, of the 12 papers analyzed in this review, three papers reported on the neck flexion angle and the position of the angle change when performing the chin-tuck maneuver. In terms of the tools used to measure the angle, two papers used VFSS ${ }^{2,23}$ and one paper used digital video ${ }^{21}$. Among the two papers using VFSS, Ra et al. ${ }^{2}$ reported that the optimal angle was $17.5^{\circ}$ when the neck flexion angle was measured based on the angle between the line connecting the mandible and $\mathrm{C} 2$ and the line connecting $\mathrm{C} 2$ and $\mathrm{C} 6$ in the chin-tuck position. Kim et al. ${ }^{23}$ reported that when images of the oral and pharyngeal processes of swallowing in the chin-tuck position were analyzed, changes in the angle and position were clear at $\mathrm{CO}$. Steele et al. ${ }^{21}$ used LabView to visualize the movements of markers attached to goggles worn by patients before and after the chin-tuck maneuver. They found that the most natural neck angle was $19^{\circ}$ (on average), which is a similar result to that reported by Ra et al. $\left(17.5^{\circ}\right)$. However, as the terms defining the chin-tuck position and the reference points for measuring the angles used in the three papers were different, it is difficult to confirm whether these results actually indicate consistency. In addition, Ko et al. ${ }^{24}$ revealed that the chin-tuck maneuver was effective but noted the limitation that neck flexion angles could not be accurately measured, resulting in biased results. This is demonstrated in continuing study by Chin-tuck, in which the neck angles are not accurately measured, and other studies have confirmed that definitions of the chin-tuck position vary 
slightly. Therefore, it is thought that additional research is needed to enhance consistency in terms of the position, terms, and measured values used in previous studies and to accurately measure the neck angle.

This study had limitations in that it did not include all papers identified in the systematic review and that only three papers were selected out of the numerous databases searched. Nevertheless, the significance of this review lies in that the literature review was conducted according to clearly specified PRISMA standards. Finally, this study confirms that the chintuck position has a positive effect on swallowing in patients with varied characteristics. Based on this study, it is expected that more treatment effects will be understood through additional research that can supplement existing studies, such as further investigation on the positions, angles, and effects associated with the chin-tuck maneuver. Overall, these findings can be used to aid dysphagia treatment, as well as to guide future research.

\section{ACKNOWLEDGEMENTS}

This work was supported by the National Research Foundation of Korea (NRF) grant funded by the Korea government (MSIT) (No. 2020R1F1A1070621).

\section{REFERENCES}

1. Navaneethan U, Eubanks S. Approach to patients with esophageal Dysphagia. The Surgical clinics of North America. 2015;3:483-9.

2. Ra JY, Hyun JK, Ko KR, Lee SJ. Chin tuck for prevention of aspiration: effectiveness and appropriate posture. Dysphagia. 2014;5:603-9.

3. Teramoto S. Novel preventive and therapuetic strategy for post-stroke pneumonia. Expert review of neurotherapeutics. 2009;8:1187-200.

4. Leigh JH, Oh BM, Seo HG, Lee GJ, Min Y, Kim K, et al. Influence of the chin-down and chin-tuck maneuver on the swallowing kinematics of healthy adults. Dysphagia. 2015;1:89-98.

5. Lazarus CL. History of the Use and Impact of Compensatory Strategies in Management of Swallowing Disorders. Dysphagia. 2017;1:3-10.

6. Terre R, Mearin F. Effectiveness of chin-down posture to prevent tracheal aspiration in dysphagia secondary to acquired brain injury. A videofluoroscopy study. Neurogastroenterology and motility : the official journal of the European Gastrointestinal Motility Society. 2012;5:414-9, e206.

7. Clark HM, Shelton N. Training effects of the effortful swallow under three exercise conditions. Dysphagia. 2014;5:553-63.

8. McCullough GH, Kim Y. Effects of the Mendelsohn maneuver on extent of hyoid movement and UES opening post-stroke. Dysphagia. 2013;4:511-9.

9. Logemann JA. The role of the speech language pathologist in the management of dysphagia. Otolaryngologic clinics of North America. 1988;4:783-8.

10. Welch MV, Logemann JA, Rademaker AW, Kahrilas PJ. Changes in pharyngeal dimensions effected by chin tuck. Archives of physical medicine and rehabilitation. 1993:2:178-81.

11. Hyun SE, Bang H, Jung SH. Effect of Chin Tuck Maneuver on Aspiration and Pharyngeal Residues Evaluated Using Simultaneous Videofluoroscopic Swallowing Study and Fiberoptic Endoscopic Evaluation of Swallowing. The Korean DYSPHAGIA Society. 2016;2:70-5.

12. Bülow M, Olsson R, Ekberg O. Videomanometric analysis of supraglottic swallow, effortful swallow, and chin tuck in healthy volunteers. Dysphagia. 1999;2:67-72.

13. Solazzo A, Monaco L, Del Vecchio L, Tamburrini S, Iacobellis F, Berritto D, et al. Investigation of compensatory postures with videofluoromanometry in dysphagia patients. World journal of gastroenterology. 2012;23: 2973-8.

14. Henry OK. Muscle Testing: Techniques of Manual Examination. Lucille Daniels Marian Williams Catherine Worthingham. The Quarterly Review of Biology. 1948;4: 374-5.

15. Woo HS. (The) effects of cranio-cervical flexion on activation of swallowing-related muscles in stroke patients and age-matched healthy adults. Seoul, Graduate School, Yonsei University; 2013.

16. Logemann JA. Evaluation and treatment of swallowing disorders. 1998.

17. Okada S, Saitoh E, Palmer JB, Matsuo K, Yokoyama M, Shigeta $\mathrm{R}$, et al. What is the chin-down posture? A questionnaire survey of speech language pathologists in Japan and the United States. Dysphagia. 2007;3:204-9.

18. Jadad AR, Moore RA, Carroll D, Jenkinson C, Reynolds DJ, Gavaghan DJ, et al. Assessing the quality of reports of randomized clinical trials: is blinding necessary? Controlled clinical trials. 1996;1:1-12.

19. Young JL, Macrae P, Anderson C, Taylor-Kamara I, Humbert IA. The Sequence of Swallowing Events During the Chin-Down Posture. Am J Speech Lang Pathol. 2015; 4:659-70.

20. Matsubara K, Kumai Y, Kamenosono Y, Samejima Y, Yumoto E. Effect of three different chin-down maneuvers on swallowing pressure in healthy young adults. 
The Laryngoscope. 2016;2:437-41.

21. Steele CM, Hung D, Sejdic E, Chau T, Fraser S. Variability in execution of the chin-down maneuver by healthy adults. Folia phoniatrica et logopaedica : official organ of the International Association of Logopedics and Phoniatrics. 2011;1:36-42.

22. Alghadir AH, Zafar H, Al-Eisa ES, Iqbal ZA. Effect of posture on swallowing. African health sciences. 2017;1: 133-7.

23. Kim JY, Hong JT, Oh JS, Jain A, Kim IS, Lim SH, et al. Influence of neck postural changes on cervical spine motion and angle during swallowing. Medicine. 2017;45: e8566.

24. Ko JY, Shin DY, Kim TU, Kim SY, Hyun JK, Lee SJ. Effectiveness of Chin Tuck on Laryngeal Penetration: Quantitative Assessment. Dysphagia. 2021.

25. Fraser S, Steele CM. The Effect of Chin Down Position on Penetration-Aspiration in Adults with Dysphagia. Canadian Journal of Speech-Language Pathology and Audiology. 2012;2:142-8.

26. Palmer PM, McCulloch TM, Jaffe D, Neel AT. Effects of a sour bolus on the intramuscular electromyographic (EMG) activity of muscles in the submental region. Dysphagia. 2005;3:210-7.

27. Logemann JA, Pauloski BR, Colangelo L, Lazarus C, Fujiu M, Kahrilas PJ. Effects of a sour bolus on oropharyngeal swallowing measures in patients with neurogenic dysphagia. Journal of speech and hearing research. 1995; 3:556-63.

28. Ding R, Logemann JA, Larson CR, Rademaker AW. The effects of taste and consistency on swallow physiology in younger and older healthy individuals: a surface electromyographic study. Journal of speech, language, and hearing research : JSLHR. 2003;4:977-89.

29. Balou M, McCullough GH, Aduli F, Brown D, Stack BC, Jr., Snoddy P, et al. Manometric measures of head rotation and chin tuck in healthy participants. Dysphagia. 2014;1:25-32

30. Saconato M, Chiari BM, Lederman HM, Goncalves MI. Effectiveness of Chin-tuck Maneuver to Facilitate Swallowing in Neurologic Dysphagia. International archives of otorhinolaryngology. 2016;1:13-7. 